\title{
Personality Factors of Choosing Adaptation Strategies in a Different Cultural Environment by Labor Migrants from Ukraine
}

\section{Особистісні чинники вибору трудовими мігрантами з України стратегій адаптації в інокультурному просторі}

Received: June 30, 2020

\begin{abstract}
The paper presents empirical research on personality factors of choosing adaptation strategies in a different cultural environment by labor migrants. The study determines three major adaptation strategies: integration, assimilation and marginalization. It establishes that integration and assimilation are means of solving the crisis of social identity. Personal identity acquires features of mature positive identity, when labor migrants integrate into a different cultural environment of a country of their employment. If a migrant chooses the strategy of assimilation, then personal identity has a tendency to approach to diffusive, "fuzzy" identity with indefinite life cycles, a decreased level of self-respect, a lack of internal integrity and uniformity. A marginal status of labor migrants in a country of employment causes an intensification of the crisis of personal identity, when migrants are not satisfied with the situation of employment abroad, but they do not see opportunities for selfrealization in Ukraine. Factor analysis made it possible to establish an adaptation structure of
\end{abstract}

Accepted: August 12, 2020

\author{
Written by: \\ Olena Blynova ${ }^{13}$ \\ https://orcid.org/0000-0003-3011-6082 \\ Ihor Popovych ${ }^{14}$ \\ https://orcid.org/0000-0002-1663-111X \\ Nataliia Semenova ${ }^{15}$ \\ https://orcid.org/0000-0002-5247-7439 \\ Yevheniia Kashyrina ${ }^{16}$ \\ https://orcid.org/0000-0003-4683-3270 \\ Olena Ursulenko ${ }^{17}$ \\ https://orcid.org/0000-0001-5423-3334 \\ Oksana Kononenko ${ }^{18}$ \\ https://orcid.org/0000-0001-8676-7410
}

\footnotetext{
${ }^{13}$ Doctor of Psychological Sciences, Full Professor of Department of General and Social Psychology, Kherson State University, Kherson, Ukraine.

${ }^{14}$ Doctor of Psychological Sciences, Full Professor of Department of General and Social Psychology, Kherson State University, Kherson, Ukraine.

${ }^{15}$ Candidate of Pedagogical Sciences, Associate Professor of Department of Pedagogy, Eastern European National University named after Lesia Ukrainka, Lutsk, Ukraine

${ }^{16}$ Candidate of Psychological Sciences, Associate Professor of Department Social Psychology and Social Work, Volodymyr Dahl East Ukrainian National University, Severodonetsk, Ukraine.

${ }^{17}$ Graduate student, Department of General and Social Psychology Kherson State University, Kherson, Ukraine.

18 Doctor of Psychological Sciences, Professor of Department Differential and Special Psychology, Odessa I. I. Mechnikov National University, Odessa, Ukraine.
} 
labor migrants consisting of five major factors $(72.43 \%)$.

Key words: intolerance, affiliation, motivation, communication, anxiety. ситуація праці за кордоном, але й в Україні він не бачить можливостей для самореалізації. Встановлено, що чинниками вибору стратегії працевлаштування $\epsilon$ відкритість досвіду, екстраверсія, сумлінність, схильність до згоди. Факторним аналізом встановлено структуру адаптації трудових мігрантів, що складається 3 п'яти основних факторів (72.43\%).

Ключові слова: інтолерантність, афіліація, мотивація, комунікація, тривожність.

\section{Introduction}

The current wave of Ukrainian emigration is probably the most powerful one in the history of our nation. According to the studies in the area of migration, Ukraine is the country of the origin of labor migration and the country entering the top ten in the world by the number of citizens who are willing to go abroad to seek employment.

According to the official statistics data approximately 4.5 millions of labor migrants from Ukraine are abroad; if we take into consideration non-regulated migrants, this figure can increase to 7 million people, these data were recorded at "State Migration Service" (2020). In the structure of labor force of Ukraine there is a many-million contingent of persons, for whom labor migration solves an employment problem and is a primary source of income. Among labor migrants there are more individuals who are engaged in unskilled labor abroad, even if they have a higher education. In such cases migrants get much lower wages than native-born citizens do, however, their payments are much higher than in Ukraine (Blynova, 2011; Ivanova \& Boluto, 2017).

The current state of labor migration of Ukrainian citizens abroad to seek employment is characterized by a number of contradictions, the main of them are the following: between a constantly increasing number of individuals, for whom labor abroad is a main way to selfrealization, and negative consequences for an individual, families, professional communities and the country on the whole; between the necessity to create conditions for more successful adaptation of labor migrants, at the international level as well (for instance, concluding agreements between countries, legalization of the status of a labor migrant), and a high risk of transformation of temporary labor migration into constant labor migration, that will cause irreversible losses of Ukraine's population (Blynova et al., 2019; Dmitriev, 2015).
However, it is evident that such an important aspect as social and psychological adaptation of migrants in the countries of their employment requires scientific and applied studies. The impossibility for a labor migrant to adapt to the demands of a social environment causes a social conflict which is traced in a closed mode of life, a reduction in the contacts with the external world, aggressive behavior in social reality, violation of ethical standards and legal norms, ignoring those values which are characteristic of this community (Hoppe \& Fujishiro, 2015). One of the main features of adaptation is adequacy of migrants' reaction to the impact of a new environment, firstly, on the essential changes of external conditions of their vital activity and internal psychological state.

Both characteristics of migrants and features of interacting cultures affect the success of adaptation. In a single process of social and psychological adaptation we can distinguish socio-cultural adaptation (or acculturation) as a process resulting in changes of external behavioral strategies under the influence of the demands of a new socio-cultural environment, and psychological adaptation as a process resulting in an internal balance and psychological satisfaction in a new socio-cultural context (Soldatova et al., 2002).

An individual's entering a different sociocultural environment, acquiring one or another form of culture of a different nation as a representative of their nation, occurring in the process of interaction, is considered as a process of acculturation. Psychological acculturation is a process of changes in an individual's psychology, in this case we mean changes of value orientations, role-related behavior, social aims of individuals, whose group undergoes the effect of general acculturation (Baynova et al., 2017; Blynova, 2016; Gorodetska, 2014). 


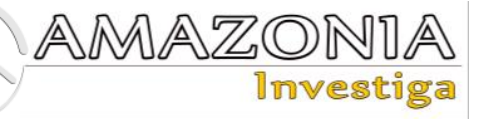

Particular attention in in such studies is paid to the analysis of psychological well-being, mental and spiritual health of migrants, and the success of adaptation is determined through a feeling of consent and harmony with the surroundings (Gritsenko et al., 2014; Kuznetsova, 2013; Melzer, 2011; Mokretsova \& Khrustaleva, 2015). The analysis of acculturation changes is most vividly reflected in using the concept "culture shock" or shock of transition, or "acculturation stress" by the scientists (Konstantinov, 2014; Tabor \& Milfont, 2011).

G. Soldatova highlights that the majority of the scientists examining culture shock tried to determine the difficulties facing migrants, and typical reactions to one or another situation. Less attention has been paid to personality aspects of culture shock, types of people, feeling shock to a greater or lesser degree, determinants of personal reactions and shock duration (Soldatova et al., 2002).

A psychological direction of the research on the process of adaptation is focused not only on examining difficulties of the process of adaptation in a different cultural environment, but also on practical problems of searching for successful strategies for adaptation of migrants in new life conditions. The researchers analyze J. Berry's approach to the classification of acculturation strategies and maintain that this approach is well known and widely represented in ethno-psychological and socio-cultural studies:

"Assimilation - a migrant is oriented toward identification with a new culture, acquiring its cultural values and gradual substitution of their own cultural values with them; segregation - the minority deny the culture of the majority and preserve their cultural features; marginalization a migrant identifies himself or herself neither with this or that culture; it can be a result of the impossibility to maintain their own cultural identity and the lack of a desire for building and developing positive relationships with a group of a cultural majority; integration - preserving their own cultural legacy along with friendly attitude towards the culture of the majority"'(Soldatova et al., 2002).

We have a scientific interest in the research on social and economic reasons of labor migration, determining the dependence of labor migration on economic stability of a country (Pronchev et al., 2019), female entrepreneurship (Pinkovetskaia et al., 2019), human rights and globalization (Arbeláez-Campillo et al., 2018). It was empirically proved and substantiated that migration of young people is a factor that curbs economic growth (Lobova \& Kletskova, 2018). Sociological analyzing was used as an instrument to determine content features of the relationships between labor migrants and native residents of the region under study (Vinokurova et al., 2017). We consider the research on personality factors of choosing adaptation strategies in a different cultural environment by labor migrants as the determination of the respondents' types of identity and the establishment of a factor structure of psychological and socialpsychological adaptation of labor migrants from Ukraine.

Hypothesis. We assume that the research on the types of identity and a factor structure of labor migrants' adaptation in a different cultural environment will allow obtaining significant empirical results to develop a program of preventive measures and overcoming negative consequences of labor migration for personality.

Purpose of the research is to determine personality factors of choosing adaptation strategies in a different cultural environment by migrants from Ukraine.

\section{Methodological Framework of the Research}

Methodological foundations of the empirical research on the types of identity and a factor structure of labor migrants' adaptation in a different cultural environment are the complex of methodological measures and psycho-diagnostic instruments tested by the researchers when examining sensory regulation in the situation of uncertainty (Halian et al., 2020a; Kononenko et al., 2020), mental states of expectations of activities (Halian et al., 2020b; Popovych, 2019; Popovych et al., 2020; Tsiuniak et al., 2020), and also when investigating social and psychological factors of migration readiness of Ukrainian students (Blynova et al., 2019; 2020), researche results of technologies of psychological wellbeing restoration of internally displaced persons (Volodarska, 2019).

Participants. The research participants were 87 persons who experienced employment abroad (Poland, Hungary, Slovakia); 45 of them were men $(51.70 \%)$ and 42 women $(48.30 \%)$. The inquiry was conducted in Kherson region (Ukraine). The age of the majority of the respondents $(55.20 \%)$ was in the category " $30-45$ years old" - the most economically active group of the population, $18.40 \%$ of the migrants - 1829 years old, $22.90 \%$ - in the category " $46-55$ 
years old". Taking into account the specific character of the Ukrainians' employment (especially of the women of a preretirement age) in some countries, we also considered labor migrants older than 55 years $(3.50 \%$ of the respondents).

To conduct the research we created an author's questionnaire, consisting of six blocks: 1. Demographic data, education, the field of study and the area of employment before going abroad; 2. Motifs for going abroad to seek employment and general estimation of the phenomenon of labor migration for the country; 3. Migrants' life experience; 4. Social and psychological adaptation of migrants in a country of employment (main criteria - employment, participation in the social life of a country of employment; material well-being); 5. Psychological adaptation (main criteria physical health, psychological well-being, satisfaction with interpersonal relationships) (Blynova, 2011; Blynova et al., 2019).

To determine quantitative characteristics of personal and professional identity of labor migrants we used "Methods to determine personal identity" and "Methods to determine professional identity" L. Schneider (Schneider, 2007).

Personality traits causing adaptivity of labor migrants were examined by means of "The fivefactor personality questionnaire" ("Big five"), containing the following basic scales: Openness to experience, Conscientiousness, Extraversion, Agreeableness and Neuroticism (R. R. McCrae, P. Jr. Costa adapted by L. Burlachuk and D. Korol'ov) (Burlachuk \& Korol'ov, 2000).

Statistical analysis. Statistical processing of the empirical data was performed by means of the statistical program "SPSS" v. 23.0 and MS "Excel". Arithmetic mean value of parameters (M) and mean-square deviation (SD) were calculated. We also used factor analysis by the traditional principal component method and Varimax rotation method.

\section{Results and discussion}

The research on the types of identity of labor migrants. We will present the results of primary processing by the method "Big five" (McCrae R. R., Costa P. Jr., adapted by L. Burlachuk and D. Korol'ov) in Table 1.

Table 1.

Mean values and mean square deviations by the scales ("Big five") ( $n=87)$.

\begin{tabular}{lll}
\hline Scale $^{*}$ & M & SD \\
\hline Openness to experience & 13.72 & 3.684 \\
Conscientiousness (self-control) & 12.26 & 2.982 \\
Extraversion & 15.17 & 3.026 \\
Agreeableness (benevolence) & 13.86 & 3.167 \\
Neuroticism (emotional instability) & 15.62 & 3.274 \\
\hline
\end{tabular}

Note: "the titles of the scales in the Table correspond to the pole of the scale with high points; $\mathrm{M}-$ arithmetic mean; SD - mean square deviation.

On the basis of comparison of the obtained data with the normative values by the scales of the method we determined that there was an average level of manifestation of this trait $(M=13.72$; $\mathrm{SD}=3.684$ ) by the scale "Openness to experience"; almost identical by the number parts of the sample of labor migrants have a high or higher than the average level of openness to experience, and, respectively, a low and lower than the average level.

On the basis of such distribution of the results it is difficult to identify a common tendency probably, a part of the migrants with high indexes by the scale "Openness to experience" adapts in a new environment due to their "tolerance to uncertainty", in other words, the ability to choose the right way of behavior in unusual situations, self-confidence in interaction with new people, in new circumstances, when performing new activities; the other part of the migrants under study with low indexes compensate this trait due to social support from reference groups and a low level of aspirations.

By the scale "Conscientiousness" we obtained indexes lower than the mean values $(M=12.26$; $\mathrm{SD}=2.982$ ). We maintain that a considerable number of labor migrants with low indexes by this scale can be explained by the lack of 


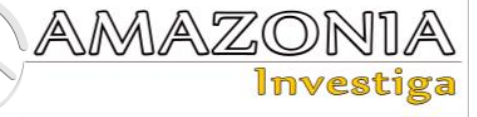

motivation for self-realization in the work done by an individual, i.e. by a low level of aspiration for professional achievements, for career development, for upgrading qualifications.

The scale "Extraversion" shows the indexes higher than the mean values $(M=15.17$; $\mathrm{SD}=3.026$ ). The ability to make contacts in communication and be interested in external events is a precondition for successful adaptation of an individual in unusual situations, in other social environments that corresponds to the data of other scientists (Konstantinov, 2014; Mokretsova \& Khrustaleva, 2015 etc.).

The scale "Agreeableness" has average indexes $(M=13.86 ; \quad S D=3.167)$, i.e. a part of the migrants (high points) is characterized by conformity, compliance, inclination to yield to other people's interests; the other group (with low points), on the contrary, is characterized by

isolation and domination of their own interests. Such conclusions are proved by the data obtained on individuality of the migrants' life practices and their aspiration to solve their problems first of all, at the same time the problems of the group or staff are minor (even the concept "colleagues", "staff" and values related to them lose their importance for many labor migrants) (Blynova, 2011).

By the scale "Neuroticism" the points were higher than the mean values $(M=15.62$; $\mathrm{SD}=3.274$ ), these results prove that the migrants of the research sample are inclined to unpleasant emotions, have a high level of sensitivity to stressogenic situations, a high level of anxiety and emotional instability.

We obtained the following data by the results of the research on the types of identity of labor migrants (see Table 2).

Table 2.

The distribution of the types of identity (\%) in the group of labor migrants $(n=87)$.

\begin{tabular}{llllll}
\hline Type & $\begin{array}{l}\text { Mature } \\
\text { identity }\end{array}$ & $\begin{array}{l}\text { Crisis of } \\
\text { identity }\end{array}$ & $\begin{array}{l}\text { Premature } \\
\text { identity }\end{array}$ & $\begin{array}{l}\text { Diffusive } \\
\text { identity }\end{array}$ & $\begin{array}{l}\text { Pseudo- } \\
\text { identity }\end{array}$ \\
\hline $\begin{array}{l}\text { Personal } \\
\text { identity }\end{array}$ & 20.7 & 32.2 & 8.0 & 28.8 & 10.3 \\
$\begin{array}{l}\text { Professional } \\
\text { identity }\end{array}$ & 11.5 & 25.3 & 6.9 & 47.1 & 9.2 \\
\hline
\end{tabular}

The data of the Table show that such types of personal and professional identity as "pseudoidentity" and "premature identity" are represented in the Table on a small scale. Mature identity in a professional area is reached only by every tenth respondent $(11.5 \%)$, this index is $20.7 \%$ in a personal area. A third of the migrants experience the crisis of personal identity $(32.2 \%)$. They solve a problem of personal selfrealization, of their life purposes and values. They decide on what to prefer at the current stage of their lives, how to shape life prospects. In a professional area this type of identity (crisis) is characteristic of a fourth of the research sample $-25.3 \%$. Such data obtained by us correspond to other studies (Khodzhiev et al., 2017; Seweryn, 2007).

The type of diffusive identity in a personal area is characteristic of about a third of the respondents $(28.8 \%)$, in a professional area about a half of the labor migrants under study $(47.1 \%)$, i.e. a considerable number of labor migrants is not able to create their own strategy of self-realization. The type of diffusive identity characterizes an individual who has lost

important purposes and values, and has no aspiration to set aims actively, he/she does not feel capable of managing the events in his/her life. This type is distinguished by a low selfesteem, detachment, indifference to one's "Self" and internal conflicts of personality. When we deal with the type of professional identity, then all the characteristics entirely relate to an individual's professional area - the data of the survey show that the migrants often have onetime or seasonal jobs, the choice of a job mainly depends on the amount of money paid for this or that type of work. The character of a job, social environment, people's respect, occupational prestige, possibilities for career development and self-realization become unimportant for migrants.

The research on a factor structure of psychological and social-psychological adaptation of labor migrants. Factor analysis of the data was used for statistical processing of 
the results. All the variables are represented in a metric system that makes it possible to expect reliability of the results. Factor analysis was conducted by the traditional principal component method and Varimax rotation method. WE obtained five major components explaining $72.43 \%$ of the dispersion of the traits in total (see Table 3).

Table 3.

The matrix of factor loadings of the migrants' psychological and social-psychological adaptation after Varimax.

\begin{tabular}{|c|c|c|c|c|c|}
\hline Components & Factor 1 & Factor 2 & Factor 3 & Factor 4 & Factor 5 \\
\hline $\begin{array}{l}\text { Availability of a job abroad (a } \\
\text { permanent job - a seasonal or one- } \\
\text { time job) }\end{array}$ & .763 & .184 & .226 & .085 & .311 \\
\hline $\begin{array}{l}\text { A degree of coincidence of } \\
\text { profession (by education) and } \\
\text { character of work abroad }\end{array}$ & .791 & .062 & -.394 & .058 & .136 \\
\hline Personal identity & 659 & .283 & .081 & .121 & .154 \\
\hline $\begin{array}{l}\text { Satisfaction with a job abroad (by } \\
\text { the questionnaire) }\end{array}$ & .217 & .322 & .021 & .034 & .682 \\
\hline $\begin{array}{l}\text { Confidence in cross-cultural } \\
\text { communications }\end{array}$ & .635 & .178 & .123 & .031 & .049 \\
\hline Professional identity & .646 & .148 & .376 & .106 & .067 \\
\hline Significance of family relationships & .107 & .203 & .542 & .089 & .027 \\
\hline Openness to experiece & .641 & .188 & .051 & .037 & .048 \\
\hline Conscientiousness & .279 & .591 & .115 & .026 & .098 \\
\hline Extraversion & .598 & .251 & .029 & .018 & .071 \\
\hline Agreeableness & .237 & .564 & .179 & .111 & .009 \\
\hline $\begin{array}{l}\text { Satisfaction with personal } \\
\text { achievements }\end{array}$ & .212 & .151 & .092 & .745 & .113 \\
\hline Satisfaction with health & .027 & .091 & .148 & .629 & .181 \\
\hline $\begin{array}{l}\text { Satisfaction with communication } \\
\text { with friends and families }\end{array}$ & .185 & .269 & -.681 & .108 & .009 \\
\hline Support (external and internal) & .317 & .558 & .046 & .145 & .084 \\
\hline Neuroticism & .054 & .129 & .662 & .216 & .314 \\
\hline Dispersion, $\%$ & 25.54 & 20.97 & 11.34 & 7.56 & 7.02 \\
\hline$\sum$ dispersion, $\%$ & 25.54 & 46.51 & 57.85 & 65.41 & 72.43 \\
\hline Value & 6.704 & 4.113 & 2.538 & 1.576 & 1.215 \\
\hline
\end{tabular}

Note: The loadings of the significant variables are given in bold type.

The analysis of the factors obtained makes us think that the first three of them (explain $57.85 \%$ of the total dispersion) can be correlated with the three strategies of migrants' adaptation in different socio-cultural conditions: integration, assimilation and marginalization. We can clearly distinguish two main variants of solving the crisis of social and personal identity of Ukrainian labor migrants in a different socio-cultural environment - integration and assimilation. "Integration" is meant as equality, involvement into new socio-cultural conditions on a par, maintenance of a positive evaluation of one's own cultural legacy and ethnic authenticity and respect for traditions, customs and rules of a country of employment. It is "integration" that gives all reasons to maintain professional integrity, and as a result, professional awareness, for internal harmonization, conformity and balance of personality traits, i.e. for maintenance of professional and personal identity.

"Assimilation" implies "dissolution" in a different culture, a loss of a migrant's ethnic identity that in some extreme cases can be manifested in the aspiration to use the language of a country of employment even in everyday life, to dress, communicate, celebrate in the way characteristic of a country of employment. We can assume that assimilation as a strategy of a migrant's adaptation in a country of employment does not assist in maintaining professional identity. It is characteristic of individuals without any special professional education, who did not work in the area of their occupation therefore they agree to any unskilled hard jobs. 


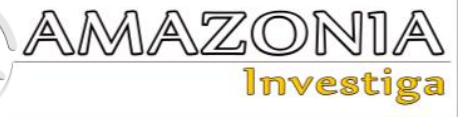

The strategy of "marginalization" - an individual between "two worlds" - causes an intensification of the crisis of identity, manifesting itself in the lack of psychological well-being, dissatisfaction with their own social status, professional achievements, family status and personality.

Factor 4 and Factor 5 are interpreted in a more complicated and ambiguous way, but they can also be explained as certain variants of the strategies of labor migrants' adaptation in a country of employment.

Factor 1 has the highest loading or the highest information value (it explains $25.54 \%$ of the dispersion). We maintain that this factor can be identified as "integration". Its positive pole is determined by the positive poles of the variables: "availability of a job abroad; a permanent job" (.763); "a degree of coincidence of profession (by education) and character of work abroad" (.791); "professional identity" (.646); "confidence in cross-cultural communications" (.635); "openness to experience" (.641); "personal identity" (.659); "extraversion" (.598). The negative pole is determined by the opposite poles of the variables.

Firstly, this factor is determined by two variables: "availability of a job abroad (a permanent job - a seasonal job)" and "a degree of coincidence of profession (by education) and character of work abroad", i.e. our data show that the most successful adaptation in new sociocultural conditions with the strategy of "integration" is characteristic of those labor migrants who work in their area of occupation and have a permanent job. Positive mature professional identity enters this factor with a high factor loading, i.e. it is necessary to add that the labor migrants who are aware of themselves as representatives of a particular professional group, have a positive attitude towards it, work in their area of occupation, are capable of realizing their professional aims, adapt abroad more efficiently. This set of traits ensures an emigrant's confidence in the situations of crosscultural communication and, when the level of professional identity is high, positive mature personal identity.

It is necessary to mention that the variables "satisfaction with a job abroad" (.217) and "social support" (.317) entered Factor 1 "Integration" with a rather low factor loading, showing that orientation to the possibility of earning "good money" abroad and availability of migrant social networks for successful adaptation of Ukrainian labor migrants in this case are not determinative factors.

Factor 2 (the information value is $20.97 \%$ ): the positive pole is determined by the following variables - "support" (.558); "satisfaction with a job abroad" (.322); "agreeableness, benevolence" (.564); "conscientiousness (honesty)" (.591). In our opinion, this factor can be called "assimilation".

The variable "satisfaction with a job abroad" entered Factor 2 "assimilation", since the content of the suggested variants of the responses for this question of the questionnaire emphasizes forced and obedient acceptance of the situation of a job abroad, even if we receive a quite high point by this trait: "Are you satisfied with your employment abroad?" - "Yes, this is the only possibility to earn money for my family"; "Yes, in any way it is better than to work in Ukraine now"; "Yes, it is a possibility to see how to work and live" etc.

"Agreeableness" enters the second factor with a high factor loading, since this personality trait indicates conformal ways to react and adapt, benevolence, inclination to work in a team, orientation to a group, group objectives and rules etc., and enables an individual to become "like everyone", "dilute in a community", acquire general features and modes of behavior in everyday situations, at home and at work.

Attention should also be paid to a high factor loading of the trait "support" - migrants assimilate faster, if they have friends, among local dwellers as well, build good relationships with their neighbors, work-mates, employers etc., in other words, have a chance to receive different types of support - information, emotional and instrumental.

Factor 3 explains $11.34 \%$ of the dispersion, the positive pole of this factor is determined by the variable - "significance of family relationships" (.542); "neuroticism" (.662); the negative pole is described by the variable: "satisfaction with communication with families" (-.681). In addition, the negative pole of this factor also included the following variables - "professional identity" (-.376); "a degree of coincidence of profession (by education) and character of work abroad" (-.394) with a low factor loading, but, in our opinion, quite evidently. Thus, this factor can be interpreted as "marginality".

In the content of this factor a major role is played by significance of family relationships with a 
high factor loading (.542), that emphasizes the value of families for migrants, the variable "satisfaction with communication with families" (-.681) has a high, but negative factor loading, that indicates the presence of conflicts in this area for migrants, i.e. there are contradictions between the aspiration to provide financial assistance for their families, but they have to leave them for it, and the aspiration to be together with their families. The variable "neuroticism" (.662) entered this factor that demonstrates a decrease in the level of migrants' psychological wellbeing. Since psychological well-being is a criterion of successful psychological adaptation in a country of employment, it allows concluding about the state of psychological disadaptation, followed by emotional disorders. Low factor loadings of the other variables of this factor somewhat reduce reliability of interpretation, but at least they allow indicating the tendency: "professional identity" entered with a negative pole, i.e. it is a question of diffusive professional identity or an intensification of the crisis of professional identity; a factor loading of the variable "a degree of coincidence of profession (by education) and character of work abroad" also has a negative pole, i.e. there is a divergence between migrants' professional qualifications, obtained in an educational institution in Ukraine, and the work they have to do abroad. We can assume that such a situation is characteristic of migrants with a high educational degree, who have to do hard, unskilled and non-prestigious work.
Factor 4 determines $7.56 \%$ of the total dispersion, it depends on the variables: "satisfaction with personal achievements" (.745); "satisfaction with health" (.629). Probably, this factor describes individualized strategies of self-realization and adaptation abroad, combining positive emotional evaluation of life and its meaning, it is determined by an individual's own aspirations, efforts and actual results which are explained on the basis of internal experience. Productivity and the feeling of life satisfaction are enhanced by a positive evaluation of one's health.

Factor 5 has the information value of $7.02 \%$ and is determined by the variables "satisfaction with a job abroad" (.682) and "Availability of a job abroad (a permanent job - a seasonal or one-time job)" (.311). These variables explain the adaptation strategy of those migrants who have a permanent job, and they are entirely satisfied with it; probably, it is not a considerable group of migrants who work in the area of their occupation, earn enough money and feel professional self-realization.

The following factors $\mathrm{F}$ insignificant $\left(\sum \mathrm{FI}\right)$ have a loading outside the limits of the total dispersion of the variables ( 0.972 and less). Thus, the results of the empirical processing reflect five major factors $(72.43 \%)$ and one total factor including insignificant factors $(27.57 \%)$. The factors determined by us established the factor structure of psychological and social-psychological adaptation of labor migrants (see Figure 1).

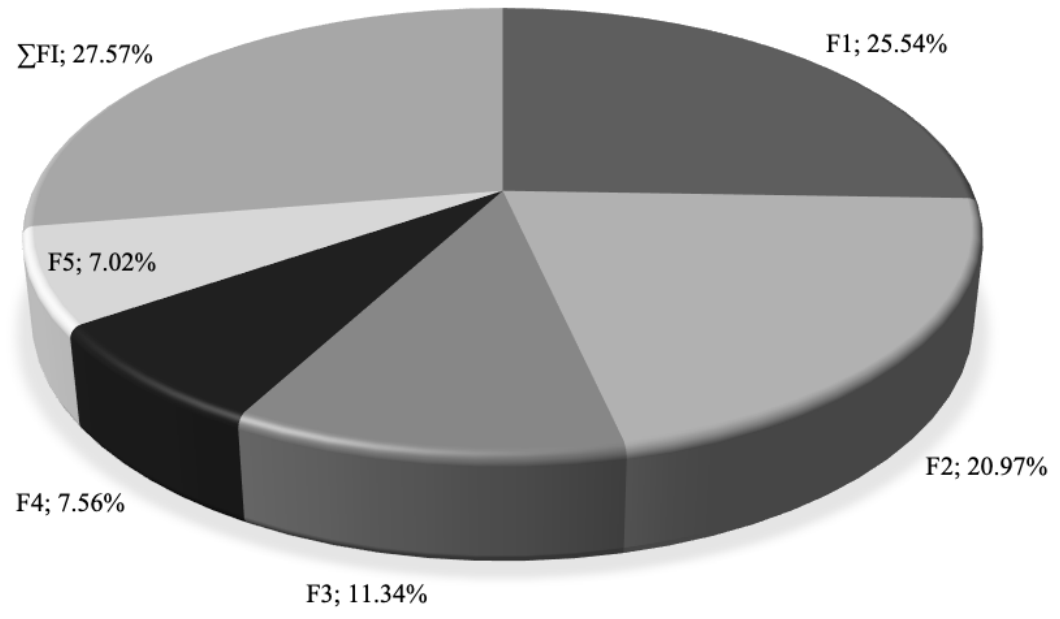

Figure 1. The factor structure of labor migrants' adaptation. 


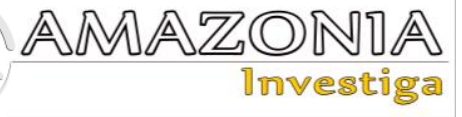

Conclusions

Three main adaptation strategies in a country of employment are characteristic of Ukrainian labor migrants - integration, assimilation and marginalization. Integration and assimilation having their specificity in the process of migrants' adaptation are the means of solving the crisis of social identity, at the same time the strategy of marginalization causes an intensification of the crisis. The determinative factor distinguishing these strategies is availability of a permanent job in the area of occupation abroad contributing to the development of mature positive professional identity. In terms of "integration" into a receiving community - emigrants work in the area of their occupation maintaining a high level of professional self-respect. If migrants choose the strategy of assimilation, they work mainly on a permanent basis, but do non-prestigious unskilled work, causing diffusive professional identity with a low level of professional selfawareness. In the case of "marginalization" there are more temporary, seasonal or one-time jobs, entirely unrelated to migrants' area of occupation. It causes migrants' strong dissatisfaction with their status, social position and work abroad.

Personal identity acquires features of mature positive identity, when labor migrants integrate into a different cultural environment of a country of their employment. If a migrant chooses the strategy of assimilation, then personal identity has a tendency to approach to diffusive, "fuzzy" identity with indefinite life cycles, a decreased level of self-respect, a lack of internal integrity and uniformity. A marginal status of labor migrants in a country of employment causes an intensification of the crisis of personal identity, when migrants are not satisfied with the situation of employment abroad, but they do not see opportunities for self-realization in Ukraine.

Personality factors of choosing the strategy of employment are openness to experience, extraversion, consciousness and agreeableness.

Factor analysis made it possible to establish the structure of labor migrants' adaptation consisting of five major factors (72.43\%).

Our hypothesis is confirmed, the obtained data are important for development a program of preventive measures and overcoming negative consequences of labor migration for personality.

\section{Acknowledgments}

The research was conducted within the framework of fundamental scientific practical themes of the Department of General and Social
Psychology of Kherson State University, the state registration number is 0119U101096.

\section{Bibliographic references}

Arbeláez-Campillo, D.; Rojas-Bahamón, M. J.; Arbeláez-Encarnación, T. (2018). Apuntes para el debate de las categorías ciudadanía universal, derechos humanos y globalización. Notes for the debate of the categories universal citizenship, human rights and globalization. Cuestiones Políticas, 34(61), 139-160.

Baynova, M. S., Evstratova, T. A., Petrov, A. V., Sulyagina, Yu. O. \& Zhaoxia, Ye. (2017). Modern social problems of labor migration in Russia. Revista ESPACIOS, 38(46), Page 7. Retrieved from: https://www.revistaespacios.com/a17v38n46/17 384607.html

Blynova, O., Chervinska, I., Kazibekova, V., Bokshan, H., Yakovleva, S., Zaverukha, O. \& Popovych I. (2020). Social and Psychological Manifestations of Professional Identity Crisis of Labor Migrants. Revista Inclusiones, 7(3), 93-105.

Blynova, O. Ye. (2011) Labor migration of the population of Ukraine in the socio-psychological dimension. Kherson: RIPO.

Blynova, O. Ye. (2016). Socio-psychological adaptation of forced migrants: approaches and problems of studying the phenomenon of acculturation. Scientific Bulletin of Kherson State University, 3(1), 111-117.

Blynova, O. Ye., Popovych, I. S., Bokshan, H. I., Tsilmak, O. M., \& Zavatska, N. Ye. (2019). Social and Psychological Factors of Migration Readiness of Ukrainian Students. Revista ESPACIOS, 40(36), Page 4. Retrieved from: https://www.revistaespacios.com/a19v40n36/in 194036.html

Burlachuk, L. F. \& Korolev, D. K. (2000). Adaptation of the questionnaire for the diagnosis of five personality factors. Psychology Issues, 1, 126-134.

Dmitriev, A. V. (2015). Conflict Migration: Theoretical and Practical Issues. Sociological science and social practice, 1, 16-29.

Gorodetska, G. I. (2014). Between "here" and "there": the marginalization of Ukrainian labor migrants. Ukrainian society, 2, 7-17. Retrieved from: http://nbuv.gov.ua/UJRN/Usoc_2014_2_3 Gritsenko, V. V., Efremenkova, M. N., Murashchenkova, N. V. \& Smotrova, T. N. (2014). Families of labor migrants: sociopsychological adaptation to the conditions of forced separation. Smolensk: Smolensk University of the Humanities.

Halian, A., Halian, I., Burlakova, I., Shevchenko, R., Lappo, V., Zhigarenko, I. \& Popovych, I. 
(2020a). Emotional Intelligence in the Structure of Adaptation Process of Future Healthcare Professionals. Revista Inclusiones, 7(3), 447-460.

Halian, I. M., Halian, O. I., Gusak, L. Ye., Bokshan, H. I. \& Popovych, I. S. (2020b). Communicative Competence in Training Future Language and Literature Teachers. Revista Amazonia Investiga, 9(29), 530-541. DOI: http://dx.doi.org/10.34069/AI/2020.29.05.58

Hoppe, A. \& Fujishiro, K. (2015). Anticipated job benefits, career aspiration, and generalized self-efficacy as predictors for migration decisionmaking. Int. J. Intercultural Relations, 47, 13-27. Ivanova, T. \& Boluto, A. (2017). External labor migration in Ukraine: problems and consequences. Problems and prospects of economy and management, 2(10), 29-33.

Khodzhiev, M., Izmerov, N. F. \& Bukhtiyarov, I. V. (2017). Examination of social and psychological factors casuing occupational stress in labor migrants. Analiz Riska Zdorov'û, 3 , 109-117. DOI 10.21668/health.risk/2017.3.13.eng

Kononenko, O., Kononenko, A., Stynska, V., Kachmar, O., Prokopiv, L., Katolyk, H. \& Popovych, I. (2020). Research of the factor structure of the model of world view settings at a young age. Revista Inclusiones, 7(3), 98-116.

Konstantinov, V. V. (2014). Adaptation process and labor migration. Penza psychological messenger PSYCHOLOGY-NEWS.RU, 1, 60-72.

Kuznetsova, S. A. (2013). Migration attitudes as a subject of socio-psychological research. Social psychology and society, 4, 34-45.

Lobova, S. V. y Kletskova, E. V. (2018). Youth migration as a factor of detaining the regional economic development. Revista ESPACIOS, 39(34), page 32. Retrieved from: https://www.revistaespacios.com/a18v39n34/18 393432.html

Melzer, S. M. (2011). Does Migration Make You Happy? The Influence of Migration on Subjective Well-Being. Journal of Social Research \& Policy, 2(2), 73-92.

Mokretsova, O. G. \& Khrustaleva, N. S. (2015). Actual issues of adaptation of labor migrants. Bulletin of the South Ural State University, 8(2), 112-116.

Pinkovetskaia, I., Kryukova, L., Arbeláez, D., Rojas-Bahamon, M. (2019). Female Entrepreneurship: Types of Economic. Activity. Tarih kultur ve sanat arastirmalari dergisi-journal of history culture and art research, 8(2), 253-265.
Popovych, I. S. (2019). Psychology of Social Expectations of Personality: Methodology, Theory and Practice. Kherson: OLDI-PLUS. Popovych, I., Borysiuk, A., Zahrai, L., Fedoruk, O., Nosov, P., Zinchenko, S. \& Mateichuk, V. (2020). Constructing a Structural-Functional Model of Social Expectations of the Personality. Revista Inclusiones, 7, Especial, 154-167.

Pronchev, G. B.; Lyubinov, A. P., Proncheva, N. G. y Tretiakova, I. V. (2019). Social and economic causes of labor migration in contemporary Russia. Revista ESPACIOS, 40(32), page 13. Retrieved from: https://www.revistaespacios.com/a19v40n32/19 403213.html

Schneider, L. B. (2007). Personal, gender and professional identity: theory and diagnostic methods. Moscow: Moscow Psychological and Social Institute.

Seweryn, O. (2007). Identity Change as a Consequence of the Migration Experience. In Imagining Frontiers, Contesting Identities. Pisa: University Press.

Soldatova, G. U., Shaigerova, L. A., Kalinenko, V. K. \& Kravtsova, O. A. (2002). Psychological assistance to migrants: trauma, cultural change, identity crisis. Moscow: Sense.

State Migration Service (2020). Electronic resource. Access mode: http://dmsu.gov.ua Tabor, A. S. \& Milfont, T. L. (2011). Migration change model: Exploring process of migration on a psychological level. Int. J. Intercultural Relations, 35(6), 818-832.

Tsiuniak, O., Pyslar, A., Lialiuk, G., Bondarenko, V., Kovtun, O., Los, O. \& Popovych, I. (2020). Research of interdependence of variables and factor structure of masters' readiness for innovative pedagogical activity. Revista Inclusiones, 7(3), 427-452.

Vinokurova, A. V., Ardalyanova, A. Yu., Kostina, E. Yu., Orlova, N. A. y Zhurbey, E. V. (2017). Labor migrants and their families in the Russian Far East: A sociological analysis. Revista ESPACIOS, 38(62), page 25. Retrieved from:

https://www.revistaespacios.com/a17v38n62/17 386225.html

Volodarska, N. D. (2019). Technologies of psychological well-being restoration of internally displaced persons. Insight: the psychological dimensions of society, 1, 79-83. DOI: 10.32999/2663-970X/2019-1-12 